\title{
AN UNPUBLISHED COIN OF PONTIUS PILATE- AND SOME SPECULATIONS ABOUT HIS CAREER
}

\section{$D B$ Saddington (University of the Witwatersrand) and U R D Vogel $\uparrow$}

Some years ago Professor Ursula Vogel's husband was given a coin of Pontius Pilate at a congress in Israel. Although a specimen of a well-known type, it may be of interest to publish it here.

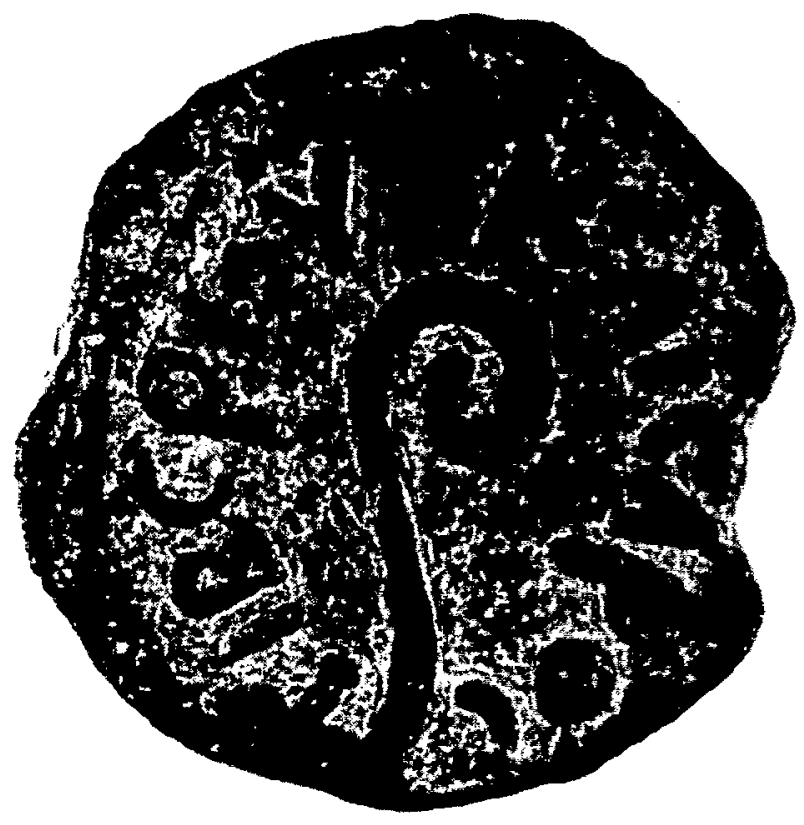

Obverse

Lituus, with the crook to the r.; inscr. TIBEPIOT KAILAPOE

An earlier version of this paper was delivered at the Twenty-First Conference of the Classical Association of South Africa in Bloemfontein in 1995. 


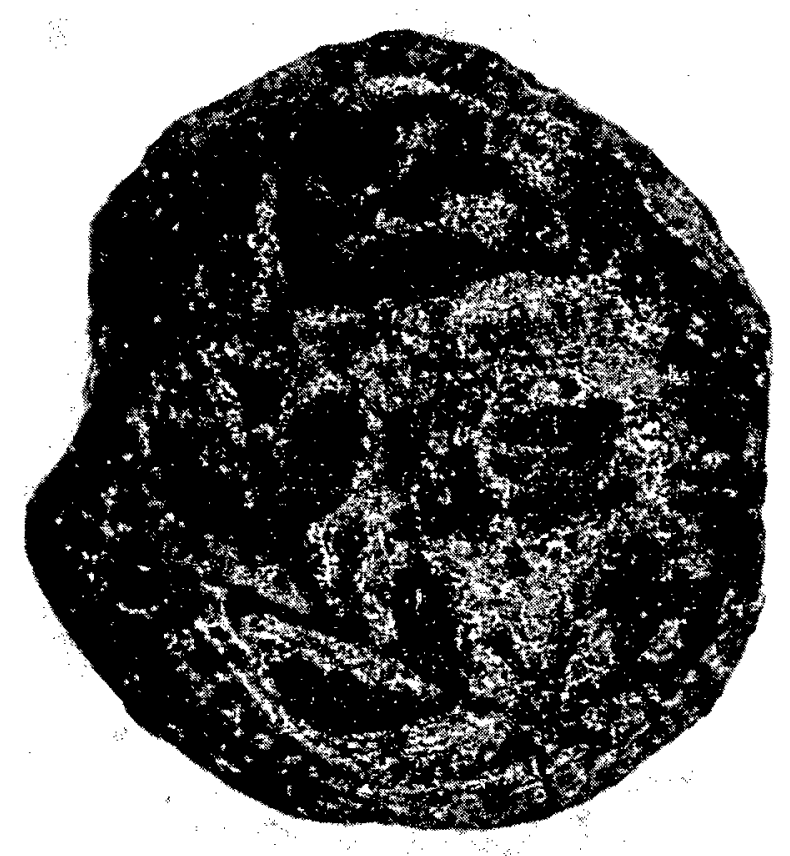

Reverse

Date within a garland with berries, tied below; inscr. IZ

The reverse shows a garland and bears the date in Greek of IZ, i.e., the 17th year of the principate of Tiberius or AD 30. The obverse has the legend TIBEPIOr KAILAPO $\Sigma$, "of Tiberius Caesar". The obverse features a lituus, a curved staff used by Roman priests called augurs when marking out ritual spaces of significance for divination.

The previous Roman governors of Judaea who issued coinage generally portrayed palm trees or ears of corn on their coins. It has been suggested that Pilate was choosing to be deliberately offensive to the Jews by featuring a Roman religious object. ${ }^{1}$ But 26 specimens of this particular coin-type have been found on Masada ${ }^{2}$ alone: surely the Zealots there would have avoided it if it had been offensive. In this connection it may be recalled that Jesus dealt with an awkward question posed by the orthodox by pointing out that the coins they were using were Roman denarii with a portrait of the emperor Tiberius on them (Mk 12:13-17). It was stipulated that the shekels used to pay for animals for sacrifice in the temple in Jerusalem had to be those of Tyre (Schürer 1979:272). Yet the Tyrian shekel carried a portrait of

1 As, for example, by Rappaport 1984:42f.

2 Cf. Meshorer 1989:96f. The coin is illustrated in BMC (Palestine) 1965:259, no. 70. 
their god Melkart (who was identified with the Greek Hercules). Had Pilate really wished to offend he would have put a portrait of Tiberius on the coins.

Several other incidents in the governorship of Pilate may now be placed in their context. Josephus records his introduction by night of military standards with representations of the emperor on them into Jerusalem. (As governor, Pilate resided in the coastal city of Caesarea, where most of his forces were quartered, and only came to Jerusalem on special occasions. The Romans excused the Jews from the imperial cult, allowing them instead to sacrifice daily on behalf of the emperor in the Temple. ${ }^{3}$ Thus there need be no statues of the emperor in the city.) Pilate's action aroused such widespread passive resistance that he was forced to remove the standards from Jerusalem.

But it is not quite clear what actually occurred. Josephus reports the incident twice. In his earlier, less "Jewish" work, the Jewish War (BJ 2.169-174), he stated that Pilate introduced "images of Caesar, which are called standards" into Jerusalem. Pilate's troops were not soldiers from a legion, but auxiliaries, and little is known about the standards of auxiliary regiments. ${ }^{4}$ In the later Antiquities of the Jews (18.55-59) he specifically states that images were contrary to Jewish law. Pilate had "brought busts of Caesar, which were attached to the standards" into Jerusalem. (Josephus states further that previous governors did not enter the city with standards having such "ornaments".) The "images" could hardly be "called" standards, as Josephus says in the first account. Accordingly, the second version is to be preferred. In either case Pilate was making a conscious decision to introduce an aspect of the expression of devotion to the emperor into the Holy City.

A similar incident is related by Philo. ${ }^{5} \mathrm{He}$ relays it in a speech purported to have been made by the Jewish king (Herod) Agrippa I to the emperor Gaius, trying to persuade him to rescind his order to have his statue placed in the Temple of Jerusalem. Agrippa is made to say that Pilate set up golden shields in the palace of Herod in the Holy City, but ensured that they were aniconic: only what Philo calls an "obligatory" inscription on them recording the dedicator (Pilate) and the dedicand

Philo. Leg. 157, 317; Jos. BJ 2.197; Schürer 1979:311f.

On Roman military standards, cf. Domaszewski 1972:69ff.

Philo Leg. 299-305. Some would identify the "golden shields" incident with that of the standards reported by Josephus. This does not seem necessary: cf. Smallwood, ad loc. and Pelletier ad loc. (with Excursus VIII). For a detailed discussion, cf. Lémonon 1981:212ff.; idem, 1992:765ff. Precisely how the inscription included something forbidden $(\tau \iota \tau \hat{\omega} \nu$ $\dot{\alpha} \pi \eta \gamma o \rho \varepsilon v \mu \varepsilon \dot{\varepsilon}(\omega \nu)$ is not clear. The inscription as a whole may have seemed offensive: as Seston $(1954: 292 \mathrm{f} .=1980: 127 \mathrm{f}$.) suggests, the honours ascribed to Augustus on the shield set up in his honour (cf. below) implied that he was closer to a god than to man. If Pilate followed the wording known from the copy of the shield preserved in Arles (AE 52, 165) the inscription would have included the phrase "for (the emperor's) piety towards the gods" (pietatis ergo deos). These words could have been regarded as "forbidden", especially when displayed in

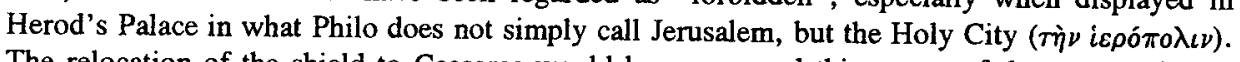
The relocation of the shield to Caesarea would have removed this aspect of the provocation at least. 
(the emperor Tiberius) caused offence. (As governor, Pilate would have used the palace of Herod as his headquarters in Jerusalem.) The precise issue at stake is unclear. Herod himself had given offence by setting up a golden eagle above the entrance to the Temple ${ }^{6}$ in Jerusalem. The eagle had long been a symbol of royalty: was Herod asserting his unwelcome kingship too close to the Temple? Prominent Romans had long been honoured with shields, usually with images on them. Augustus ( $R G$ 34.2) had been given a golden shield inscribed with his "virtues" and set up in the Senate House in Rome. What aspect of the "obligatory" inscription aroused opposition is not clear. That, as Philo makes Agrippa say, the shields were "dedicated" in honour of Tiberius and were later placed in the Sebasteion or Precinct for the Imperial Cult in Caesarea suggests that they had something to do with the cult. Presumably it was their original setting that gave offence to the Jews: their erection in Jerusalem had been an affront to the "ancient tradition of the city".

What these incidents show is a man intent on stressing his loyalty to the emperor. This must have been Pilate's main motive. But he could not have been unaware that by doing so in terms of the imperial cult in the city of Jerusalem he was on sensitive ground. As noted above, Augustus had made a special concession to the Jews in this area and, if Philo is to be believed, Tiberius confirmed this when he ordered that the shields be removed from Jerusalem and set up in the "gentile" city of Caesarea.

Josephus ${ }^{7}$ reports another occasion on which Pilate offended Jewish sensibilities. He took money from the Sacred Treasury known as the Corbonas ${ }^{8}$ to pay for an aqueduct for Jerusalem which he was having built. Whether his intention was to be deliberately provocative can of course not be established. The improvement of the water supply was an eminently "Roman" thing to do.

Two "law and order" incidents are known. Little can be established about an apparent confrontation with some Galileans reported in the New Testament (Lk 13:1). More is known of a clash with the Samaritans (Jos. $A J$ 18.85-89). A false prophet had collected a large crowd by promising to reveal the place where Moses had buried sacred vessels. Apparently some of the crowd were armed and Pilate dispersed them with bloodshed. He took many prisoners, later executing the more prominent among them. It was this incident which eventually led to the governor of Syria sending Pilate to Rome to give an account of the matter. The violent suppression of religiously motivated crowds, however, was a common feature of Roman rule by the governors who where in charge of Judaea from AD 10 to 66, when the Great Revolt broke out.

Nor need much be said about Pilate's conduct of the trial of Jesus. For him it was probably one of many hearings of those accused of being politically disaffected. As is well known, the Gospels present his approach in a fairly favourable light.

Jos. $B J$ 1.648-655; $A J$ 17.149-167.

Jos. $B J 2.175-177 ; A J 18.60-62$.

The word is used in Mt 27:6. 
It may be noted that Pilate's name appears on an inscription found in Caesarea. It reads as follows: [---]s Tiberieum/[---]ntius Pilatus/[prae]fectus Iuda[ea]e/[---]. "Pontius Pilate, prefect of Judaea, [dedicated?] (a building?) in honour of Tiberius." 9

Unfortunately it is too fragmentary to be able to say what it commemorated but it seems to refer to something in honour of the emperor Tiberius.

The actions of Pilate discussed above seem to show him as devotedly loyal to the emperor and an upright, if insensitive, administrator apt to over-react in a crisis.

It would be of interest to establish his earlier career. Unfortunately this is not known: nor are the careers of his predecessors in Judaea known (Saddington 1996:2425ff.). But something of the milieu from which he came may plausibly be deduced from typical careers of governors of his status in the western part of the empire. Thus a Sex. Pedius Lusianus Hirrutus (ILS 2689) was an army officer who reached the important position of primipilus or chief centurion in a legion before being made administrator of a recently conquered area in the Alps and in southern Germany with an auxiliary force of light-armed troops under his command. On his return to Italy he became mayor of his home town and then was mayor a second time as the representative of Germanicus, Tiberius' son by adoption. The link with the imperial house should be noted.

At a lower level than Pilate or Hirrutus but in the East there was Herennius Capito. ${ }^{10} \mathrm{He}$ is known from Philo and Josephus for having put the future king Herod Agrippa $I$ in an embarrassing position by demanding that he repay his debts: he reported the matter to Tiberius. He did this in his capacity as a procurator or administrator of an imperial property in Judaea. Before being appointed procurator he had been a military tribune or senior officer in a legion and a commander of an auxiliary cavalry unit. This information is known from an inscription on a silver bust to Tiberius which he had had made in his home town in Italy on behalf of a deceased centurion from a legion in the East.

Onomastics may be of use. "Pontius" is a name from Samnium, a poor and hilly area in south central Italy. It is attested from the 4th century BC onwards. It suggests that Pilate's origins were Italian, like those of Hirrutus and Herennius Capito. "Pilatus", however, is very rare indeed. It has been suggested that Pilate chose it for its military connections (Weber 1971). The pilum was a javelin, the legionary's main weapon. Had Pilate performed a spectacular feat with a javelin? Or was he made a primus pilus or chief centurion like Hirrutus? The cognomen is undeniably military.

It is possible to sharpen our image of Pilate on the basis of the above. He seems to have belonged to the class of those who came from fairly remote areas of Italy and rose through service in the army to equestrian status. Their attitude to Tiberius,

9 AE 63,104 . Pilate's title in this inscription is prefect of Judaea. The term procurator for governors of the province is post-Tiberian.

10 Philo Leg. 199; Jos. $A J$ 18.158, 163; $A E$ 41, 105. For his career, cf. Fraccaro 1940:136ff.; PIR $^{2}$ H 103; PME H 13. 
who had established his military reputation before he became emperor, was similar to that of the historian Velleius Paterculus of somewhat higher social status-he rose from the equestrian to the senatorial order. Velleius (2.104.3f.; cf. 2.97.44) is extravagant in his praise of Tiberius and his care for the men in his armies. It would be interesting to know whether Pilate had served personally under Tiberius, or one of his sons, as Hirrutus probably did under Germanicus. His actions with the standards and the golden shield and probably even with the Tiberieum are surely to be interpreted as giving public expression to the loyalty he felt towards the emperor which was typical of his class at the time.

His appointment to Judaea may perhaps be regarded as unsuitable. A century later Pliny the Younger wrote a letter to a governor who was taking up his appointment in Greece to remind him to establish good relations with the elite of the province and to be aware of their cultural traditions. ${ }^{11}$ Pliny and his correspondent belonged to the highly cultured senatorial class and Greece was a much easier province to govern than Judaea.

Pilate's behaviour in Judaea suggests the military man who had not cultivated the finesse to appreciate important cultural features operative in his province. $\mathrm{He}$ is not accused of the open corruption and extortion practised by several of his successors in Judaea. But he seems either to have acted with excessive force or to have weakly backed down when faced with formidable confrontation. But one must not forget that the armed forces at his disposal were limited: the main Roman army in the area was based in Syria to the north.

Postscript: Since this was written a valuable article by Bond (1996) on the coins of Pilate has appeared. She is also of the opinion that his coinage was not intended to give offence. However, whether it can be regarded as evidence for an "attempt to integrate Judaea further into the empire" (1996:260) remains to be proved.

\section{BIBLIOGRAPHY}

Bond, H K 1996. The coins of Pontius Pilate: Part of an attempt to provoke the people or to integrate them into the Empire? Journal for the study of Judaism $27: 241-262$.

BMC (= Catalogue of Greek coins in the British Museum) Palestine [1914] 1965. Ed. G F Hill. Reprint. London: British Museum.

Domaszewski, A von [1885] 1972. Die Fahnen im römischen Heere. In Aufsätze zur römischen Heeresgeschichte, 1-80. Reprint. Darmstadt: Wissenschaftliche Buchgesellschaft.

Fraccaro, P 1940. C. Herennius Capito di Teate. Athenaeum 18:136-144.

Lémonon, J-P 1981. Pilate et le gouvernement de la Judée. Paris: Gabalda.

11 Plin. Ep. 8.24. Cf., a century earlier, Cicero's letter to his brother ( $Q . f r .1 .1$ ) on maintaining good relations with the prominent in his province of Asia. 
Lémonon, J-P 1992. Ponce Pilate. Aufstieg und Niedergang der römischen Welt 2.26.1:741-778.

Meshorer, Y 1989. The coins of Masada. In Masada I: The Yigael Yadin excavations 1963-1965, 71-98. Jerusalem: Israel Exploration Society.

Rappaport, U 1984. Numismatics. In Cambridge history of Judaism, 25-59. Cambridge University Press.

Schürer, E 1979. The history of the Jewish people in the age of Jesus Christ. Transl. G Vermes et al. Vol. 2. Edinburgh: T \& T Clark.

Saddington, D B 1996. Roman military and administrative personnel in the New Testament. Aufstieg und Niedergang der römischen Welt 2.26.3:2409-2435.

Seston, W 1954. Le Clipeus Virtutis d'Arles. Comptes rendus de l'Academie des Inscriptions 1954:286-297 = idem, 1980. Scripta varia, 121-132. Rome: École française.

Smallwood, E M [1976] 1981. The Jews under Roman rule. Reprint. Leiden: Brill. Weber, E 1971. Zur Inschrift des Pontius Pilatus. Bonner Jahrbücher 171:194-200. 